\title{
Kant's Compatibilism
}


Digitized by the Internet Archive in 2018 with funding from

The Arcadia Fund 
H U D H U D S O N

\section{Kant's}

Compatibilism

Cornell University Press · Ithaca and London 


\section{Copyright (C) 1994 by Cornell University}

All rights reserved. Except for brief quotations in a review, this book, or parts thereof, must not be reproduced in any form without permission in writing from the publisher. For information, address Cornell University Press, Sage House, 512 East State Street, Ithaca, New York 14850.

First published 1994 by Cornell University Press

\section{Library of Congress Cataloging-in-Publication Data}

Hudson, Hud.

Kant's compatibilism / Hud Hudson.

p. $\mathrm{cm}$.

Includes bibliographical references and index.

ISBN o-8014-2923-4 (alk. paper)

1. Kant, Immanuel, 1724-1804. 2. Free will and determinism.

I. Title.

B2799.F8H83 1994

$123^{\prime} \cdot 5^{\prime} 092-\mathrm{dc} 20$

Printed in the United States of America

(2) The paper in this book meets the minimum requirements of the American National Standard for Information Sciences-

Permanence of Paper for Printed Library Materials, ANSI Z39.48-1984. 
For Warren Harbison and Alan Brinton 
